\title{
Metasomatism of the Mantle Beneath Yakutia: A Quantitative Study of Secondary Chemistry and Mineralogy in Udachnaya Eclogites
}

Sobolev, V.N. ${ }^{1}$,Taylor, L.A. ${ }^{1}$, Snyder, G.A. ${ }^{1}$, Jerde, E.A. ${ }^{2}$, Neal, C.A. ${ }^{3}$, and Sobolev, N.V. ${ }^{4}$

1. Planetary Geosciences Institute, Department of Geological Sciences, University of Tennessee, Knoxville, TN 37996

2. Oak Ridge National Labs, Environmental Sciences Division, Mail Stop 6038, Oak Ridge, TN 37830

3. Department of Civil Engineering and Geological Sciences, University of Notre Dame, IN 46556

4. Institute of Mineralogy and Petrography, Siberian Branch of the Russian Academy of Sciences, Novosibirsk, Russia

We present the first attempt at quantizing metasomatism in Udachnaya eclogites. Reconstructed whole-rock ("pristine") compositions were compared to measured whole-rock compositions for both major- and trace-elements for ten Udachnaya eclogites. This resulted in $\Delta$ values, i.e., the difference between pristine and measured whole-rock compositions. There is a general depletion in $\mathrm{SiO}_{2}, \mathrm{Na}_{2} \mathrm{O}$, and $\mathrm{FeO}$, and enrichment in $\mathrm{TiO}_{2}, \mathrm{~K}_{2} \mathrm{O}, \mathrm{MgO}$, and $\mathrm{LREE}$ in the measured whole-rocks. This quantitative approach demonstrates that, although the major metasomatic source affecting Udachnaya eclogites was similar to host kimberlite in general enrichment/depletion patterns, it was distinctly different in terms of major- and trace element abundances. The metasomatic agent inferred from Udachnaya eclogites "truly" represents mantle metasomatism which occurred prior to kimberlite eruption.

Introduction. Alteration in mantle xenoliths from kimberlites significantly complicates studying their petrogenesis. This alteration is the result of long residence times in the mantle, during which the xenoliths experience a wide variety of processes at variable P\&T. One of these processes, metasomatism, is yet to be quantitatively understood and described with respect to fluid(s) compositions involved in this phenomenon. This has been difficult because of the possible sources for these fluids - e.g., only mantle vs. late kimberlite. In fact, metasomatism has often been used in the past as a panacea for many chemical and petrological problems relating to mantle xenolith genesis.

Using whole-rock chemistry and reconstructed primary whole-rock compositions obtained from modal analyses and mineral chemistry, theoretically, one should be able to determine the composition of the metasomatic fluid(s). However, this is only possible when all chemical changes in the rock are due to modal and not cryptic metasomatism, i.e., primary minerals are chemically homogeneous. Sobolev et al. (1994) showed that diamondiferous eclogites from the Udachnaya kimberlite are unusual in the virtual absence of compositional variations within and between primary minerals of a given xenolith. Thus, these rocks represent a unique suite of samples where most, if not all, chemical changes made by metasomatic fluids lead to the appearance of secondary minerals (modal metasomatism) and not to chemical zonations and intergrain variations in primary phases. This permits one to use mineral modes obtained from point-counting to reconstruct pristine whole-rock compositions and to compare these to measured whole-rock analyses.

In this study, the above mentioned comparison is used to discern the nature of the metasomatic fluids. A total of 10 eclogites from the Udachnaya kimberlite of the Yakutian diamondiferous province were selected for this study based on freshness of the xenoliths. The eclogites in this study were obtained from different horizons of the Udachnaya mine and are relatively fresh. A gross assumption is made that weathering does not contribute appreciably to the alteration of the samples, i.e., that this alteration is due solely to metasomatic modification of the primary rocks. This assumption is supported by the general lack of weathering of the host kimberlite.

Mineralogy and Petrography. The mineralogy and petrography of the samples have been described in detail by Sobolev et al. (1994) and Snyder et al. (1997). Udachnaya eclogites are characterized by the virtual absence of compositional zoning (Sobolev et al., 1994), in contrast to 
eclogites from other Yakutian localities (e.g., Mir kimberlite, Beard et al., 1996), indeed, from eclogites worldwide.

Udachnaya eclogites contain a distinct assemblage of secondary minerals which include phlogopite, amphibole, serpentine, feldspar, pyroxene, various sulfides, calcite, and spinel.

Metasomatism By subtracting the PWR composition from the MWR, a $\Delta$ for each element (Fig.1) is obtained. This value includes not only the contribution from the metasomatic fluid, but also the contribution by the alteration of garnet and clinopyroxene. A $10 \%$ error (uncertainties in modal abundances) was taken into account. Resultant $\Delta$ values less than this error range were assumed to be indistinguishable from zero and are not indicated on Fig.1. There is general enrichment in $\mathrm{MgO}$ and $\mathrm{K}_{2} \mathrm{O}$, and depletion in $\mathrm{SiO}_{2}$ and $\mathrm{Na}_{2} \mathrm{O}$ for all samples; $\mathrm{Al}_{2} \mathrm{O}_{3}$ is depleted in all but eclogite 237/79; $\mathrm{TiO}_{2}$ is enriched in all but samples 25/84, 35/1, 236/79. All measured REE patterns are enriched in LREE and MREE relative to reconstructed patterns (Fig.2). HREE abundances do not possess a general enrichment/depletion pattern.

The compositions of secondary minerals were taken into account in the interpretation of the results. Obtained modes were also compared to the compositions of fluid inclusions trapped in fibrous diamonds (data from Schrauder and Navon, 1994; Schrauder and Koeberl, 1994). In order to evaluate whether kimberlite was the source for the metasomatic fluid, ratios of various elements for PWR and MWR were compared to kimberlite ratios. Different metasomatic models were tested based upon composition of the alteration and its correlation with $\Delta$ values.

Conclusions: The quantitative approach, with its enrichment/depletion signatures, demonstrates that the major metasomatic source for Udachnaya eclogites was similar to that expected from a kimberlite, but different mainly in terms of absolute major- and trace- element abundances. The fluids appear to have been more enriched in $\mathrm{TiO}_{2}, \mathrm{~K}_{2} \mathrm{O}, \mathrm{Cl}, \mathrm{FeO}$ and LREE (up to 300-600 ppm of La) than the kimberlites. These metasomatic agents also may have contained significant amounts of $\mathrm{F}, \mathrm{CO}_{2}$, and $\mathrm{H}_{2} \mathrm{O}$. A carbonatite-like fluid has affected samples $35 / 1$ and $51 / 3$, and resulted in much higher $\mathrm{Ca}$ contents (due to $\mathrm{CaCO}_{3}$ ) of the MWR values for these samples. It is believed that the major metasomatizing fluids which modified the Udachnaya eclogites probably represent older mantle metasomatism, and their introduction, in timing and composition, was different from that of the host kimberlite.

\section{References}

Beard, B. L., Fraracci, K. N., Taylor, L. A., Snyder, G. A., Clayton, R. N., Mayeda, T. K. and Sobolev, N. V., 1996, Petrography and geochemistry of eclogites from the Mir kimberlite, Russia: Contrib. Mineral. Petrol., v. 125, p. 293-310.

Schrauder, M. and Koeberl, C., 1994, Trace element analyses of fluid-bearing fibrous diamonds from Jwaneng (Botswana) by neutron activation analysis: Mineral. Mag., v. 58A, p. 811-812.

Schrauder, M. and Navon, O., 1994, Hydrous and carbonatitic mantle fluids in fibrous diamonds from Jwaneng, Botswana: Geochim. Cosmochim. Acta, v. 58, p. 761-771.

Snyder, G. A., Taylor, L. A., Crozaz, G., Halliday, A. N., Beard, B. L., Sobolev, V. N., and Sobolev, N. V., 1997, The origins of Yakutian eclogite xenoliths: Journal of Petrology, v. 38, p. 85113.

Sobolev, V. N., Taylor, L. A., Snyder, G. A. and Sobolev, N. V., 1994, Diamondiferous eclogites from the Udachnaya kimberlite pipe, Yakutia, Siberia. International Geology Review: v. 36, p. 4264. 

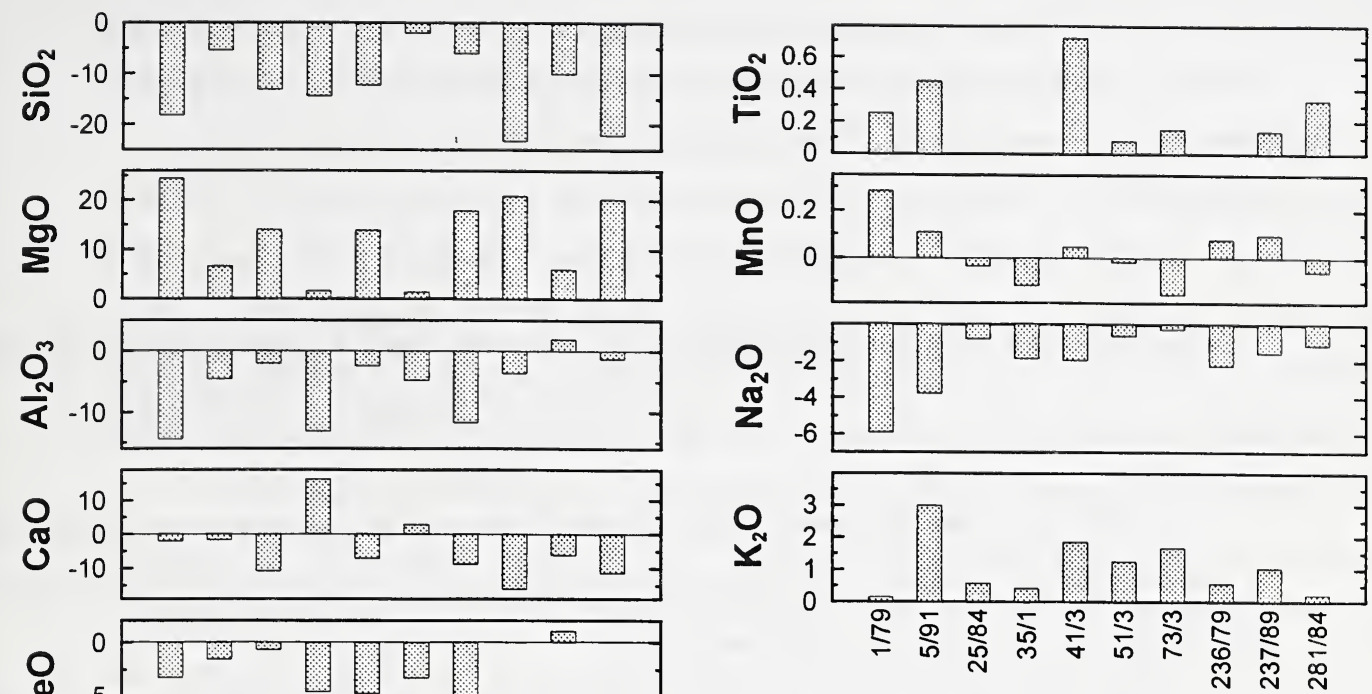

Fig.1. Absolute $\Delta$ values for the Udachnaya eclogites. $\mathrm{X}$ axis is the relative $\%$ of the constituent oxides.

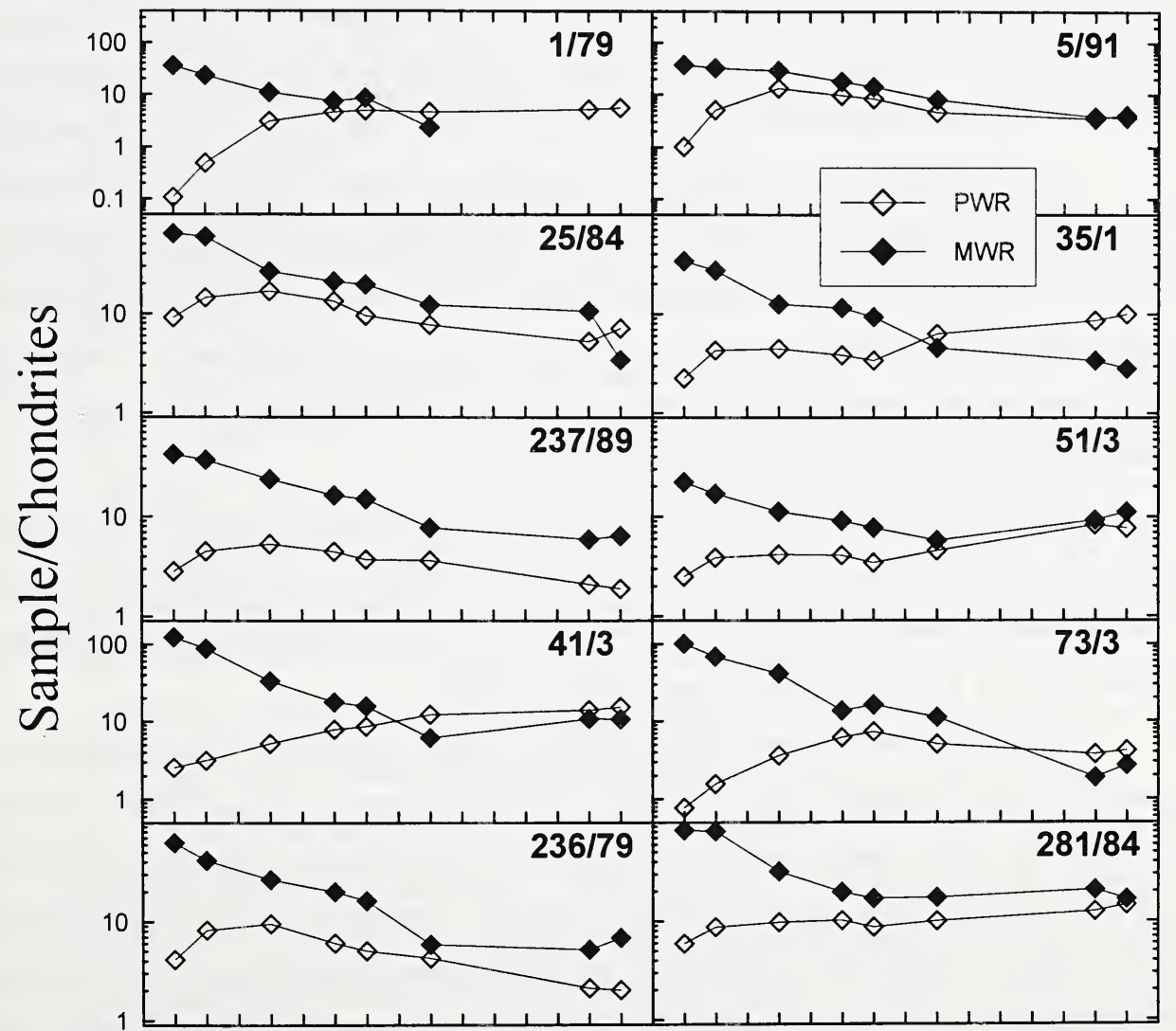

Fig. 2. REE abundances for primary whole-rock (PWR) and measured whole-rock (MWR) 